This is a revised personal version of the text of the final journal article, which is made available for scholarly purposes only, in accordance with the journal's author permissions. The full citation is:

Zhang Y. and Banks C. J. (2012) Co-digestion of the mechanically recovered organic fraction of municipal solid waste with slaughterhouse wastes. Biochemical Engineering Journal 68, 129-137. doi: 10.1016/j.bej.2012.07.017

\title{
Co-digestion of the mechanically recovered organic fraction of municipal solid waste
} with slaughterhouse wastes

\section{Author names and affiliations}

Y. Zhang ${ }^{1}$, C. J. Banks

Faculty of Engineering and the Environment, University of Southampton, Southampton SO17 1BJ, UK

\begin{abstract}
The current work aimed to resolve some long-standing questions about the potential benefits and limitations of co-digestion of slaughterhouse wastes. To achieve this, a laboratory-scale trial was carried out using the mechanically recovered organic fraction of municipal solid waste mixed with either sheep blood or a mixture of pig intestines with flotation fat. Both of these co-substrates are difficult to digest in isolation because of their high nitrogen and lipid concentrations, and are regulated as Category 3 materials under the Animal By-Products Regulations (EC 1069/2009). The results showed that at an organic loading rate of $2 \mathrm{~kg}$ VS $\mathrm{m}^{-3}$ day $^{-1}$ with the slaughterhouse material making up $20 \%$ of the load on a volatile solids basis the process could operate successfully. As the loading was increased to $4 \mathrm{~kg} \mathrm{VS} \mathrm{m}^{-3}$ day $^{-1}$ signs of inhibition appeared with both co-substrates, however, and volumetric methane
\end{abstract}

\footnotetext{
1 * Corresponding author: Tel.: +44 (0)2380 598363; fax: +44 (0)2380 677519; E-mail address: Y.Zhang@soton.ac.uk (Yue Zhang)
} 
production was reduced to a point where co-digestion gave no process advantage. The main operational problem encountered was an increase in the concentration of volatile fatty acids in the digestate, particularly propionic acid: this was thought to be a result of ammonia toxicity. The concentration of potentially toxic elements in the digestate made it unsuitable for agricultural application for food production, although the increased nitrogen content made it more valuable as a fertiliser for non-food crop use.

Keywords:

Anaerobic processes; Biodegradation; Waste treatment; Slaughterhouse waste; Product inhibition; Potentially toxic element

\section{Introduction}

Slaughterhouse wastes are potentially valuable substrates for the anaerobic digestion process due to their high energy yield. It has been estimated that the methane potential from the slaughter waste of cattle is about $1300 \mathrm{MJ}^{\text {livestock unit }}{ }^{-1}$ and from a pig about $140 \mathrm{MJ}$ livestock unit ${ }^{-1}[1]$. Biogas production from many of the fractions that make up the waste is permitted providing that the conditions of the Animal By-Products Regulations (ABPR) are met and approval by the competent authority is granted (EC 1069/2009, replacing EC 1774/2002). There are, however, some technical difficulties associated with the digestion of Category 3 slaughterhouse waste and blood. These are primarily related to long chain fatty acids (LCFA) from the degradation of lipids [2] and to ammonia released during protein decomposition [2-6]. Although it has been claimed that biogas plants can operate with permitted ABPR materials as the sole substrate [7], it was found necessary to control the quantity of blood added to avoid raising the ammonia concentration in the digesters above a critical level, as this can result in high concentrations of volatile fatty acids (VFA) and foaming problems. In later work at the same plant additional measures had to be introduced 
to reduce the total kjeldahl nitrogen $(\mathrm{TKN})$ concentration to a non-inhibitory level by direct removal of ammonia [8].

The sensitivity of methanogenic archaea to ammonia is well known, and it has been established for a long time that anaerobic consortia can acclimate to a certain extent to free ammonia [9]. During the anaerobic digestion of slaughterhouse waste, however, ammonia concentrations can rise to $15 \mathrm{~g} \mathrm{~N}^{-1}$ [10], which is well above the toxic threshold of 3-4 $\mathrm{g} \mathrm{N} \mathrm{1}^{-}$ ${ }^{1}$ suggested by a number of authors $[8,11,12]$, although the exact value depends on $\mathrm{pH}$, temperature and acclimatisation. Technical innovations can be used to lower this concentration, for example by stripping a proportion of the ammonia from a recycle stream or from the digester itself $[8,13]$.

Co-digestion of slaughterhouse wastes with other substrates has also been undertaken. Bouallagui et al. [14] used fruit and vegetable waste to improve the nutrient balance in sequencing batch anaerobic digestion. Alvarez and Lidén [15] digested a mixture of slaughterhouse waste with manure and fruit and vegetable waste in laboratory-scale digesters and showed that in all cases digestion with mixed substrates was better than with the single substrate. In Sweden there are about 10 biogas plants receiving animal by-products [16]. These are co-digested with manure and other substrates to provide buffering and essential nutrients, thus overcoming some of the operational problems associated with mono-digestion. Co-digestion of slaughterhouse waste in conjunction with animal manures is also practiced in Denmark [17]. The anaerobic co-digestion of slaughterhouse wastes with the organic fraction of municipal solid waste (OFMSW) is less common. Cuetos et al. [18-20] carried out investigations in which laboratory-scale digesters were fed on slaughterhouse waste mixed with a synthetic OFMSW composed mainly of fruit and vegetable material. In one of their studies [18] there were initial problems with accumulation of digestion intermediates, but after an acclimatisation period at low organic loading it was possible to treat the mixture and 
achieve total fat removal of $83 \%$. Digestion was carried out at ammonia concentrations between 3 and $4 \mathrm{~g} \mathrm{~N}^{-1}$, achieved by dilution of the slaughterhouse material with fresh water. The potential for co-digestion has also been investigated through modelling, again focusing on the use of co-substrates to reduce the problems associated with ammonia [21].

Slaughterhouse wastes could be an ideal substrate for co-digestion with mechanically recovered OFMSW (mr-OFMSW) as this material is low in nitrogen, and is not suited for application to land used for food production because of its high concentration of potentially toxic elements (PTE) [22]. OFMSW digestate is commonly applied to non-food crops and forestry, however, where the risk of disease transmission to farm animals is minimised. The additional nitrogen provided by the slaughterhouse wastes could be beneficial to this nonfood land application. The high energy value of the slaughterhouse wastes may also enhance the volumetric biogas yield thus improving the process economics.

The aim of this study was to determine the maximum loading that could be achieved from a mixture of slaughterhouse wastes and mr-OFMSW without dilution by fresh water and employing recirculation of the separated liquid fraction of the digestate to facilitate digester feeding and mixing, as commonly practised in full-scale plant. Sheep blood and a mixture of pig intestines with flotation fat were chosen as co-substrates due to the high concentrations of nitrogen and lipids in these two materials. The overall benefits were evaluated with respect to volumetric methane production as the main indicator of the economic viability of the process. The characteristics of the digestate (NPK and PTE) were also analysed in order to determine its potential for land application.

\section{Materials and methods}

\subsection{Substrate}

The mr-OFMSW was obtained from Bursom Recycling Centre operated by Biffa Ltd. in Leicester, UK. This waste is used as a substrate for commercial-scale anaerobic digestion 
after a further wet densiometric separation; a detailed characterisation is given in Zhang et al. [23]. One of the slaughterhouse waste fractions was obtained from Grampian Country Pork, Somerset, UK and consisted of pig intestines (including contents) (PI), and flotation fat (FF) from wastewater pre-treatment. These were mixed in the proportion of nine parts PI to one part FF on a volatile solids (VS) basis, to reflect the amounts generated in a typical pig slaughterhouse. The other slaughterhouse waste fraction was sheep blood, obtained from R W Newman \& Partners, Hampshire, UK. Table 1 gives the characteristics of these materials. In all digestion trials the co-substrates were mixed with mr-OFMSW at a ratio of 20:80 on a VS basis. The particle size of both the mr-OFMSW and the PI/FF mix were reduced before use to ensure homogeneity.

\subsection{Biochemical methane potential (BMP)}

BMP tests were performed using continuously stirred tank reactor (CSTR) digesters with a working volume of 1.41 , maintained at $36 \pm 1^{\circ} \mathrm{C}$ in a thermostatic water bath and stirred at 40 rpm. Biogas was collected by displacement of a $75 \%$ saturated sodium chloride solution acidified to $\mathrm{pH} 2$ in calibrated glass cylinders. The height of the solution in the collection cylinder was recorded by a headspace pressure sensor and logged at 5-minute intervals, as a back-up to manual readings. Vapour pressure and salt solution density were taken into account in correction of gas volumes [24]. Samples for gas composition analysis were taken from the cylinders each time they were refilled, at intervals of no more than 7 days. The tests were conducted using an inoculum to substrate ratio of 4 on a VS basis, and lasted for 100 days until there was no obvious difference in gas production between test digesters and control digesters containing inoculum only. BMP results were calculated from the difference in methane production between the test and control digesters and expressed on a VS basis.

\subsection{Digesters}


The five CSTR digesters used had a capacity of 51 with a working volume of 41 and were constructed of PVC tube with gas-tight top and bottom plates. The top plate was fitted with a gas outlet, a feed port sealed with a rubber bung, and a draught tube liquid seal through which a stainless steel asymmetric bar stirrer was inserted connected to a $40 \mathrm{rpm}$ motor mounted directly on the top plate. Temperature was controlled at $36 \pm 1^{\circ} \mathrm{C}$ by circulating water from a thermostatically controlled bath through a heating coil around each digester. Semi-continuous operation was achieved by the daily removal of digestate through an outlet port in the base of each digester, followed by substrate addition via the feed port. Biogas production was measured using tipping-bucket gas counters with continuous data logging [24].

\subsection{Inoculum}

Inoculum for the trial was taken from a digester with a working volume of 351 that had been acclimated to mr-OFMSW over a period of 140 days at an organic loading rate (OLR) of $2 \mathrm{~kg}$ $\mathrm{VS} \mathrm{m}^{-3}$ day $^{-1}$ [23]. Before use the digestate was sieved through a $1 \mathrm{~mm}$ mesh to remove any large solid particles.

\subsection{Digester operation}

For the first two months all 5 digesters were fed on mr-OFMSW without co-substrates. Two of the digesters then received the mr-OFMSW and PI/FF mix and two the mr-OFMSW and blood mix; the fifth digester continued to be fed solely on mr-OFMSW and acted as a control. In all the digesters a solids retention time (SRT) of 30 days was maintained by solids/liquid separation of the digestate in a $1 \mathrm{~mm}$ mesh sieve, with a proportion of the liquor fraction recirculated to maintain the working volume. Day 0 was the first day when co-substrates were added to the digesters, which were then operated for a period of 425 days. The OLR applied to the digesters was $2 \mathrm{~kg} \mathrm{VS} \mathrm{m}^{-3}$ day $^{-1}$ from day 0 to 190 , increasing to $3 \mathrm{~kg} \mathrm{VS} \mathrm{m}^{-3}$ day $^{-1}$ from day 191 to 350 . From day 351 to 425 this was further increased to $4 \mathrm{~kg} \mathrm{VS} \mathrm{m}^{-3}$ day $^{-1}$ in 
the digesters fed on mr-OFMSW with PI/FF and mr-OFMSW only, but the OLR remained at $3 \mathrm{~kg} \mathrm{VS} \mathrm{m}{ }^{-3}$ day $^{-1}$ in the digester fed on mr-OFMSW and blood during this period.

Between days 270 and 274 a total volume of $300 \mathrm{ml}$ of digestate was taken from each digester for use in other work (not reported here), and lukewarm tap water was used to make up the volume: this lowered the alkalinity and total ammoniacal nitrogen concentrations for around one retention time.

\subsection{Monitoring and analytical methods}

The digesters were monitored daily for biogas production and $\mathrm{pH}$. Other digestate parameters such as solids, VFA, total ammoniacal nitrogen (TAN), and alkalinity, as well as biogas composition, were analysed a minimum of once per week and often more frequently. Digestate samples were also taken for NPK and PTE analysis on day 425 at the end of the experimental run.

Total solids (TS) and VS were measured using Standard Method 2540 G [25]. pH was determined using a Jenway 3010 meter (Bibby Scientific Ltd., UK) with a combination glass electrode calibrated in buffers at $\mathrm{pH}$ 4.0, 7.0 and 9.2 (Fisher Scientific, UK). Alkalinity was measured by titration with $0.25 \mathrm{~N} \mathrm{H}_{2} \mathrm{SO}_{4}$ to endpoints of $\mathrm{pH} 5.75$ and 4.30 , allowing calculation of total alkalinity (TA), partial alkalinity (PA) and intermediate alkalinity (IA) [26]. Total Kjeldahl Nitrogen (TKN) was obtained using a Kjeltech block digester and TAN was determined using a steam distillation unit according to the manufacturer's instructions (Foss Ltd., Warrington, UK). VFA were quantified in a Shimazdu GC-2010 gas chromatograph (Shimadzu, Milton Keynes, UK), using a flame ionization detector and a capillary column type SGE BP-21. Biogas composition $\left(\mathrm{CH}_{4}\right.$ and $\left.\mathrm{CO}_{2}\right)$ was determined using a Varian star $3400 \mathrm{CX}$ Gas Chromatograph, calibrated with $65 \% \mathrm{CH}_{4}$ and $35 \% \mathrm{CO}_{2}$ (v/v). All gas volumes reported are corrected to standard temperature and pressure (STP) of $0{ }^{\circ} \mathrm{C}$, $101.325 \mathrm{kPa}$. 
Elemental composition (C, H, N, S, O) was determined using a FlashEA 1112 Elemental Analyser (Thermo Finnigan, Italy), following the manufacturer's standard procedures. Total phosphorus (TP), total potassium (TK) and PTE in digestate were first extracted in nitric acid by microwave digestion (Model MARS XR, XP-1500 Plus, CEM Corporation) and the extract filtered and diluted to $50 \mathrm{ml}$ with deionised water (Milli-Q Gradient, Millipore, Watford, $\mathrm{UK}) . \mathrm{Cd}, \mathrm{Cr}, \mathrm{Cu}, \mathrm{K}, \mathrm{Ni}, \mathrm{Pb}$, and $\mathrm{Zn}$ concentrations in the extract were determined using a flame atomic absorption spectrometer (Spectr AA-200, Varian, USA) calibrated against appropriate stock standards (Sigma Aldrich, UK; Fisher Scientific, UK). $\mathrm{Hg}$ in the extract was determined using cold vapour atomic fluorescence spectrometry (PSA 10.025 Millennium Merlin, P S Analytical Ltd., Kent, UK). Phosphorus was measured using the ammonium molybdate spectrometric method [27].

\section{Results}

\subsection{Biochemical methane potential}

Two sets of BMP tests were conducted. The first was carried out on mr-OFMSW, mrOFMSW mixed with PI/FF and mr-OFMSW mixed with blood. These gave BMP values of $0.344,0.358$ and $0.357 \mathrm{STP} \mathrm{m}^{3} \mathrm{CH}_{4} \mathrm{~kg}^{-1} \mathrm{VS}_{\text {added }}$ respectively. From these values it was possible to estimate the BMP of the co-substrate by difference, giving a BMP value for blood of $0.450 \mathrm{STP} \mathrm{m}^{3} \mathrm{CH}_{4} \mathrm{~kg}^{-1} \mathrm{VS}_{\text {added }}$, and for PI/FF of $0.474 \mathrm{STP} \mathrm{m}^{3} \mathrm{CH}_{4} \mathrm{~kg}^{-1} \mathrm{VS}_{\text {added }}$. The second set of BMP tests determined the BMP of the co-substrates directly without mrOFMSW, and gave values of $0.418 \mathrm{STP} \mathrm{m}^{3} \mathrm{CH}_{4} \mathrm{~kg}^{-1} \mathrm{VS}_{\text {added }}$ for blood and of $0.595 \mathrm{STP} \mathrm{m}^{3}$ $\mathrm{CH}_{4} \mathrm{~kg}^{-1} \mathrm{VS}_{\text {added }}$ for the PI/FF. The single substrate tests are direct measurements and should therefore be more reliable in terms of determining the properties of the individual materials; but the mixed substrate test shows how the material may react in co-digestion. The results suggest that when blood is used as the sole substrate in the BMP test some inhibition may 
occur which is overcome by co-digestion. When co-digested, the estimated contribution of blood to the final BMP was $93 \%$ of the theoretical BMP of the blood calculated stoichiometrically from its biochemical composition (Table 1), giving support to this argument. Co-digestion of the PP/FF appeared to suppress the BMP of this substrate, however, with only $71 \%$ of its theoretical potential being expressed; yet when digested without the mr-OFMSW almost all of the theoretical BMP was recovered. The BMP results highlight some of the difficulties in predicting gas production based on batch tests, and confirm the need to carry out continuous or semi-continuous simulation trials to obtain accurate gas production data and establish stability criteria.

\subsection{Semi-continuous digestion trial}

\subsubsection{Operation at OLR of $2 \mathrm{~kg} \mathrm{VS} \mathrm{m}^{-3} \mathrm{~d}^{-1}$}

Experimental results for the mr-OFMSW co-digestion are shown graphically in Figs. 1-3. The digesters ran at an OLR of $2 \mathrm{~kg} \mathrm{VS} \mathrm{m}^{-3} \mathrm{~d}^{-1}$ for 190 days, more than 6 nominal SRT. During this time, the digester fed on mr-OFMSW as the sole substrate was very stable and showed a performance and the process efficiency comparable between units and to that of the digester from which the inoculum digestate was taken. This had a specific methane production (SMP) of $0.304 \mathrm{STP} \mathrm{m}^{3} \mathrm{CH}_{4} \mathrm{~kg}^{-1} \mathrm{VS}_{\text {added}}$; a specific biogas production of (SBP) $0.529 \mathrm{STP} \mathrm{m}^{3} \mathrm{~kg}^{-1} \mathrm{VS}_{\text {added }}$; a volumetric biogas production (VBP) of $1.05 \mathrm{STP} \mathrm{m}^{3} \mathrm{~m}^{-3} \mathrm{~d}^{-1}$; a methane percentage of $57.5 \%$; a VFA concentration less than $200 \mathrm{mg} \mathrm{l}^{-1}$; a TAN concentration of $1200 \mathrm{mg}^{-1}$, and a $\mathrm{pH}$ of 7.5 . The SMP accounted for $88 \%$ of the BMP value indicating that a high proportion of the substrate is biodegradable.

The digesters running with sheep blood and also those running with PI/FF as cosubstrates both showed some signs of inhibition at the end of the first SRT. This was indicated by a reduction in the biogas methane content to 57 and $51 \%$ in the case of the PI/FF mix and blood co-substrates respectively (Fig. 1e). There was also a build-up in VFA, 
reaching $3000 \mathrm{mg} \mathrm{l}^{-1}$ with the PI/FF mix and $9000 \mathrm{mg}^{-1}$ with sheep blood (Fig. $2 \mathrm{~d}$ ). In both cases acetic acid was the predominant VFA (Fig. 3a-d). This slight inhibition may have been associated with the rapid build-up of TAN, as seen in Fig. 2b, which was not unexpected as the biodegradable carbon to TKN ratio of the sheep blood and PI/FF mixes with mr-OFMSW were 8.6 and 12.4 respectively at a $20 \%$ VS mix. At the high $\mathrm{pH}$ values under which these digesters were operating these TAN concentrations gave high free ammonia concentrations in both cases (Fig. 2c).

The pair of digesters fed with the PI/FF mix had recovered from all signs of inhibition by the end of the second retention time, indicating that the microbial consortium had acclimated to the feedstock. The system then appeared stable with a total VFA concentration of less than $300 \mathrm{mg}^{-1}$ (Fig. 2d) and methane production 10\% higher than the mr-OFMSW control (Fig. 1e).

The digesters fed with sheep blood also showed signs of recovery at the end of the second retention time, with the total VFA concentration falling to less than $1000 \mathrm{mg} \mathrm{l}^{-1}$ (Fig. 2d). This was short lived, however, as the propionic acid concentration increased rapidly over the third retention time (Fig. $3 \mathrm{c}$ and d). During this period SMP fell to $0.217 \mathrm{STP} \mathrm{m}^{3} \mathrm{CH}_{4} \mathrm{~kg}^{-}$ ${ }^{1} \mathrm{VS}_{\text {added }}$ (Fig. 1b) and methane concentration to $55 \%$ (Fig. 1e). The presence of propionic acid is not unusual when using blood as feedstock [3] and although the total VFA concentration reached $4000 \mathrm{mg}^{-1}$, with propionic acid accounting for $80 \%$ of this (Fig. 3c and d), it had dropped to $1600 \mathrm{mg}^{-1}$ at the end of the sixth retention time with acetic acid as the predominant species.

The average SMP during the sixth SRT was $0.319,0.289$, and $0.288 \mathrm{STP} \mathrm{m}^{3} \mathrm{CH}_{4} \mathrm{~kg}^{-1}$ $\mathrm{VS}_{\text {added }}$ for digesters fed on mr-OFMSW mixed with PI/FF, mr-OFMSW mixed with sheep blood and mr-OFMSW respectively, equal to $89.1,81.0$ and $83.7 \%$ of the measured codigestion BMP in each case. 


\subsubsection{Operation at OLR of $3 \mathrm{~kg} \mathrm{VS} \mathrm{m}^{-3} \mathrm{~d}^{-1}$}

After 6 retention times the OLR was increased to $3 \mathrm{~kg} \mathrm{VS} \mathrm{m}^{-3} \mathrm{~d}^{-1}$. The mr-OFMSW control quickly adapted to the increased loading and showed a similar SMP to that obtained at the lower OLR (Fig. 1b) with a 50\% increase in volumetric methane production (VMP) (Fig. 1d). VFA concentration remained below $200 \mathrm{mg} \mathrm{l}^{-1}$, TAN $1500 \mathrm{mg} \mathrm{l}^{-1}$ and $\mathrm{pH}$ 7.4.

The increase in loading produced a shock in the digesters fed with co-substrates, as can be seen from the rising VFA concentration (Fig. 2d). This was rapidly overcome in the digesters receiving PI/FF and the VFA concentration gradually reduced from its peak value of $3500 \mathrm{mg} \mathrm{l}^{-1}$, but persisted at $1000-2000 \mathrm{mg}^{-1}$ with acetic and propionic acids as the predominate species for the last 3 retention times at this loading. Performance remained good with the VMP reaching $0.99 \mathrm{STP} \mathrm{m}^{3} \mathrm{CH}_{4} \mathrm{~m}^{-3} \mathrm{~d}^{-1}$, which was $50 \%$ higher than that achieved for this pair of digesters at an OLR of $2 \mathrm{~kg} \mathrm{VS} \mathrm{m}^{-3} \mathrm{~d}^{-1}$ (Fig. 1d).

In the digesters fed with sheep blood the VFA concentrations continued to rise and reached 11,000-15,000 $\mathrm{mg}^{-1}$ during the third retention time. The $\mathrm{pH}$ remained around 8.0 (Fig. 2a), however, as the high TAN concentration of 7000-8000 $\mathrm{mg}^{-1}$ (Fig. 2b) provided buffering capacity and maintained the ratio of IA to PA at around 0.6. The SMP of this pair of digesters had decreased to $0.180 \mathrm{STP} \mathrm{m}^{3} \mathrm{CH}_{4} \mathrm{~kg}^{-1} \mathrm{VS}_{\text {added }}$ by the end of the fourth retention time (day 310 ) at this OLR (Fig. 1b); this was only $62 \%$ of the specific methane production at the lower OLR. At the end of the fourth retention time the performance of the two digesters began to diverge, with one showing a slight fall in VFA concentration (Fig. 2d) and an increase in SMP to $0.243 \mathrm{STP} \mathrm{m}^{3} \mathrm{CH}_{4} \mathrm{~kg}^{-1} \mathrm{VS}_{\text {added }}$ (Fig. 1b). In the second digester acetic acid accumulated from 5000 to $25,000 \mathrm{mg} \mathrm{l}^{-1}$ (Fig. 3d), resulting in a $\mathrm{pH}$ drop from 8.0 to 7.2 (Fig. 2a). The biogas production also dropped to $0.161 \mathrm{STP}^{3} \mathrm{~kg}^{-1} \mathrm{VS}_{\text {added }}$ (Fig. 1a) with a methane concentration of $43 \%$ (Fig. 1e). There was no further increase in OLR on these digesters and they continued to operate at $3 \mathrm{~kg} \mathrm{VS} \mathrm{m}^{-3} \mathrm{~d}^{-1}$ until day 425 . 


\subsubsection{Operation at OLR of $4 \mathrm{~kg} \mathrm{VS} \mathrm{m}^{-3} \mathrm{~d}^{-1}$ in control and PI/FF digesters}

The loading was increased on day 351 and the control digester and mr-OFMSW with PI/FF digesters ran at this loading for 75 days (2.5 retention times) until the end of the trial.

The control digester treating mr-OFMSW showed shock symptoms on increasing the load. There was a drop in specific biogas and methane production at the end of the first retention time (Fig. 1a and b) and VFA accumulated to $5000 \mathrm{mg} \mathrm{l}^{-1}$ (Fig. 2d), with acetic acid as the predominant species (Fig. 3e). There was also a slight drop in $\mathrm{pH}$ (Fig. 2a) and a reduction in the biogas methane content (Fig. 1e). The digester overcame this shock and during the second retention time the accumulated VFA was consumed and the specific methane production recovered to that achieved at an OLR of $3 \mathrm{~kg} \mathrm{VS} \mathrm{m}^{-3} \mathrm{~d}^{-1}$. VMP reached 1.25 STP $\mathrm{m}^{3} \mathrm{CH}_{4} \mathrm{~m}^{-3} \mathrm{~d}^{-1}$, double that achieved at the OLR of $2 \mathrm{~kg} \mathrm{VS} \mathrm{m}^{-3} \mathrm{~d}^{-1}$ (Fig. 1d). VFA stabilised at less than $150 \mathrm{mg} \mathrm{l}^{-1}$ (Fig. 3e), TAN at $1600 \mathrm{mg}^{-1}$ (Fig. 2b) and pH at 7.4 (Fig. 2a). It is possible that higher loadings could have been applied to this digester but this was not attempted in the current trial. It was observed that as the loading increased the rheological properties of the digestate changed as a result of its higher TS content. At the highest loading the digestate TS was $160-170 \mathrm{~kg} \mathrm{~m}^{-3}$ which was close to the limit of the mechanical mixing system of the small-scale digesters used in this study, and could also impact on operation at a larger scale.

The pair of digesters fed on mr-OFMSW with PI/FF showed a gradual rise in VFA after the loading increase, mainly contributed by propionic acid (Fig. 3a and b). TAN remained at $5000 \mathrm{mg} \mathrm{l}^{-1}$ (Fig. 2b), and a drop in pH (Fig. 2a) was observed in response to VFA accumulation, with a fall in biogas production (Fig. 1).

\subsection{Digestate characteristics}

In each case the digestate could easily be separated into its fibre and liquor fractions by sieving, and the characteristics of liquor, fibre and whole digestate at the end of the 
digestion trials are given in Tables 2-4. In the case of the control digester fed on mr-OFMSW the concentrations of $\mathrm{N}$ and $\mathrm{K}$ were 2-3 times higher in the digestate liquor than in the fibre, while the concentration of $\mathrm{P}$ was about the same in fibre and liquor. No clear trend was seen in the partitioning of PTE between digestate liquor and fibre: in general $\mathrm{Cd}, \mathrm{Pb}$ and $\mathrm{Zn}$ were at higher concentrations in the liquor and $\mathrm{Cr}, \mathrm{Cu}$, and $\mathrm{Ni}$ in the fibre.

In the co-digestion mixtures of PI/FF and sheep blood the digestate plant nutrient content was increased compared to that for mr-OFMSW alone (Tables 2-4). Because of the large proportion of mr-OFMSW in the mix the PTE content of the digestate remained high (Table 2-4), and concentrations of $\mathrm{Cu}, \mathrm{Pb}, \mathrm{Ni}$ and $\mathrm{Zn}$ in the digestate liquor, and $\mathrm{Cr}, \mathrm{Cu}, \mathrm{Pb}$, $\mathrm{Ni}$ and $\mathrm{Zn}$ in the digestate fibre and whole digestate were above typical limit values for use on agricultural land [28, 29]. Residual plastics were clearly visible in all digestates.

\section{Discussion}

The results from the study confirmed that mr-OFMSW was a suitable feedstock for digestion as a sole substrate: it had good buffering capacity with a safe TAN concentration of 1200-1600 $\mathrm{mg} \mathrm{l}^{-1}$ and a $\mathrm{pH}$ of 7.4. This was similar to the results from a previous trial using this material at an OLR of $2 \mathrm{~g} \mathrm{VS}^{-1} \mathrm{day}^{-1}$ in duplicate 35-1 digesters over 284 days [22]. The volumetric methane production reached $1.25 \mathrm{STP} \mathrm{m}^{3} \mathrm{CH}_{4} \mathrm{~m}^{-3} \mathrm{~d}^{-1}$ at the OLR of $4 \mathrm{~kg} \mathrm{VS} \mathrm{m}^{-3}$ $\mathrm{d}^{-1}$. The co-digestion of mr-OFMSW and PI/FF had higher specific methane production than the mr-OFMSW control at an OLR of 2 and $3 \mathrm{~kg} \mathrm{VS} \mathrm{m}^{-3} \mathrm{~d}^{-1}$, although the elevated VFA concentration of $1500 \mathrm{mg} \mathrm{l}^{-1}$ at an OLR of $3 \mathrm{~kg} \mathrm{VS} \mathrm{m}^{-3} \mathrm{~d}^{-1}$ indicated less favourable conditions as the OLR was increased. At the final loading of $4 \mathrm{~kg} \mathrm{VS} \mathrm{m}^{-3} \mathrm{~d}^{-1}$ the TAN concentration was around $5000 \mathrm{mg} \mathrm{l}^{-1}$ and there was a fall in $\mathrm{pH}$, increasing VFA, and a severe drop in SMP. The digesters had not recovered by the end of the trial, and the reactor conditions indicated that this was not a safe loading for this mix. 
Even at lower loadings there may be longer-term implications for running on this type of co-substrate because of the high lipid content of $125 \mathrm{~g} \mathrm{~kg}^{-1} \mathrm{VS}$ in this mix. The lipids found in food industrial waste are mainly triacylglycerides [30] consisting of a glycerol backbone with three fatty acid chains attached, which is broken down by extracellular lipases excreted by acidogenic bacteria [30-32]. The glycerol fraction is then fermented to propionate, while the LCFA are sequentially oxidised to acetic acid, formic acid, hydrogen and carbon dioxide. Lipids may, however, potentially interfere with both of the two main rate-limiting steps in the AD process: hydrolysis and methanogenesis [33]. Firstly, the non-polar lipids and LCFA may adsorb to particulate substrate, making it more resistant to enzyme attack and therefore slower to hydrolyse [34]. Secondly, adsorption of lipids and LCFA onto bacterial cells can interfere with the mass transport of solutes such as acetate, which then inhibits methanogenesis [33]. For a substrate not consisting solely of lipids, but also containing high quantities of readily degradable polysaccharides, the readily degradable materials provide a constant source of VFA while the more slowly degradable and less easily hydrolysed lipids may build up in the digester, as in the example cited by Fox and Pohland [35] of accumulation of fats and greases at the reactor inlet for anaerobic filters treating wastewaters containing lipids and polysaccharides. The easily-acidified substrates are degraded first, creating a high hydrogen partial pressure at the inlet. Since $\beta$-oxidation of the LCFA requires a low partial pressure of hydrogen, this therefore creates an environment unfavourable for lipid degradation near the inlet. Fox and Pohland [35] also looked for inhibition of hydrogenotrophic methanogenesis, but found that this was less sensitive to LCFA inhibition than acetoclastic methane production, which agrees with the results of other investigators [36, 37]. Although the current study did not investigate LCFA inhibition, this is a recognised long-term phenomenon and the impact of of lipid-rich substrates may not be realised for a substantial period of time. 
The co-digestion of mr-OFMSW and sheep blood showed stress due to the inhibitory effect of the high TAN even at a moderate OLR of $2 \mathrm{~kg} \mathrm{VS} \mathrm{m}^{-3} \mathrm{~d}^{-1}$, although this high TAN also provided enough buffering capacity to allow the digester to operate stably in these conditions. From the perspective of improving the methane yield there was, however, no advantage in adding blood as a co-substrate in the proportion used. It may have some value in improving the nitrogen content of the final digestate product, due to the very high TKN of $147 \mathrm{~g} \mathrm{~kg}^{-1} \mathrm{TS}$ in sheep blood. For co-digestion of this substrate it is recommended that the proportion added should be low enough to ensure that the total ammoniacal concentration in the digester does not exceed 3-4 $\mathrm{g} \mathrm{l}^{-1}$, a similar value to that recommended in other studies and for full-scale operation $[8,10]$.

In both cases, co-digestion at a higher OLR would probably have been possible with a lower proportion of the co-substrates, but this would not have achieved the objective of maximising volumetric methane production.

\section{Conclusions}

Using mechanically recovered OFMSW it was possible to achieve a volumetric methane productivity of $1.25 \mathrm{STP} \mathrm{m}^{3} \mathrm{CH}_{4} \mathrm{~m}^{-3} \mathrm{~d}^{-1}$ at a loading rate of $4 \mathrm{~kg} \mathrm{VS} \mathrm{m}^{-3} \mathrm{~d}^{-1}$, and a methane yield of $102 \mathrm{~m}^{3} \mathrm{CH}_{4}$ tonne ${ }^{-1}$ wet weight. At this loading the digestate total solids content was $16-17 \%$, but it was still possible to use a completely mixed single stage 'wet' digester. Co-digestion of mr-OFMSW with both the PI/FF and sheep blood co-substrates was possible at lower loading rates but as the loading rate increased there was evidence of inhibition of the process. This was indicated by an increase in the concentration of volatile fatty acids in the digestate, a reduction in the volumetric methane production, and an elevated concentration of total ammoniacal nitrogen. Although the digesters continued to operate at these higher loadings, the anticipated enhancement in volumetric methane production which is a major potential benefit of co-digestion did not occur. The use of a non-source-segregated 
waste fraction would exclude the use of these digestates on agricultural land in a number of European countries, and analysis showed that in fact the digestate could not meet PTE quality specifications for agricultural application. Co-digestion did however improve the nutrient balance of the digestate making it a more valuable product for potential use in permitted applications such as land reclamation, forestry and long-term cultivation of non-food crops.

\section{Acknowledgements}

The authors thank the UK Government's Department of the Environment Food and Rural Affairs (Defra) for funding this work through Grant number WR0212. Views expressed are the authors', and not necessarily those of Defra.

\section{References}

[1] M. Edström, A. Nordberg, L. Thyselius, Anaerobic treatment of animal byproducts from slaughterhouses at laboratory and pilot scale, Appl. Biochem. Biotechnol. 109 (2003) $127-138$.

[2] L. Masse, D.I. Massé, K.J. Kennedy, S.P. Chou, Neutral fat hydrolysis and long-chain fatty acid oxidation during anaerobic digestion of slaughterhouse wastewater, Biotechnol. Bioeng. 79 (2002) 43-52.

[3] C.J. Banks, Anaerobic digestion of solid and high nitrogen content fractions of slaughterhouse wastes, in: Environmentally Responsible Food Processing, AIChE Symposium Series, vol. 90, 1994, pp. 103-109.

[4] M.J. Broughton, J.H. Thiele, E.J. Birch, A. Cohen, Anaerobic batch digestion of sheep tallow, Water Res. 32 (1998) 1423-1428.

[5] E. Salminen, J. Einola, J. Rintala, The methane production of poultry slaughtering residues and effects of pretreatments on the methane production of poultry feather, Environ. Technol. 24 (2003) 1079-1086. 
[6] L.Y. Lokshina, V.A. Vavilin, E. Salminen, J. Rintala, Modeling of anaerobic degradation of solid slaughterhouse waste: inhibition effects of long-chain fatty acids or ammonia, Appl. Biochem. Biotechnol. 109 (2003) 15-32.

[7] IEA BIOENERGY TASK 37 Energy from biogas and landfill gas, Biogas from slaughterhouse waste: towards an energy self-sufficient industry, 2009. http://www.ieabiogas.net/_download/st_martin.pdf (accessed on 12.12.11).

[8] C. Resch, A. Wörl, R. Waltenberger, R. Braun, R. Kirchmayr, Enhancement options for the utilisation of nitrogen rich animal by-products in anaerobic digestion, Bioresour. Technol. 102 (2011) 2503-2510.

[9] I. Angelidaki, B.K. Ahring, Thermophilic anaerobic digestion of livestockwaste: the effect of ammonia, Appl. Microbiol. Biotechnol. 38 (1993) 560-564.

[10] H. Siegrist, W. Hunziker, H. Hofer, Anaerobic digestion of slaughterhouse waste with UF-membrane separation and recycling of permeate after free ammonia stripping, Water Sci. Technol. 52 (2005) 531-536.

[11] D. Karakashev, D.J. Batstone, E. Trably, I. Angelidaki, Acetate oxidation is the dominant methanogenic pathway from acetate in the absence of Methanosaetaceae, Appl. Environ. Microbiol. 72 (2006) 5138-5141.

[12] A. Schnurer, A. Nordberg, Ammonia, a selective agent for methane production by syntrophic acetate oxidation at mesophilic temperature, Water Sci. Technol. 57 (2008) 735-740.

[13] C.J. Banks, Z. Wang, Development of a two phase anaerobic digester for the treatment of mixed abattoir wastes, Water Sci. Technol. 40 (1999) 69-76.

[14] H. Bouallagui, B. Rachdi, H. Gannoun, M. Hamdi, Mesophilic and thermophilic anaerobic co-digestion of abattoir wastewater and fruit and vegetable waste in anaerobic sequencing batch reactors, Biodegradation. 20 (2009) 401-409. 
[15] R. Alvarez, G. Lidén, Semi-continuous co-digestion of solid slaughterhouse waste, manure, and fruit and vegetable waste, Renew. Energy 33 (2008) 726-734.

[16] A. Nordberg, M. Edström, Treatment of animal waste in co-digestion biogas plants in Sweden, in: The Future of Biogas in Europe II, European Biogas Workshop, October 2-4, University of Southern Denmark, Esbjerg, Denmark, 2003, pp. 24-29.

[17] I. Angelidaki, L. Ellegaard, Codigestion of manure and organic wastes in centralized biogas plants, Appl. Biochem. Biotechnol. 109 (2003) 95-105.

[18] M.J. Cuetos, X. Gómez, M. Otero, A. Morán, Anaerobic digestion of solid slaughterhouse waste (SHW) at laboratory scale: influence of co-digestion with the organic fraction of municipal solid waste (OFMSW), Biochem. Eng. J. 40 (2008) 99-106.

[19] M.J. Cuetos, A. Morán, X. Gómez, M. Otero, Anaerobic co-digestion of poultry blood with OFMSW: FTIR and TG-DTG study of process stabilization, Environ. Technol. 30 (2009) 571-582.

[20] M.J. Cuetos, X. Gómez, M. Otero, A. Morán, Anaerobic digestion and co-digestion of slaughterhouse waste (SHW): influence of heat and pressure pre-treatment in biogas yield, Waste Manage. 30 (2010) 1780-1789.

[21] I.M. Buendía, F.J. Fernández, J. Villaseñor, L. Rodríguez, Biodegradability of meat industry wastes under anaerobic and aerobic conditions, Water Res. 42 (2008) 37673774.

[22] C.J. Banks, Y. Zhang, Technical Report: Optimising Inputs and Outputs from Anaerobic Digestion Processes, Project Code WR0212, Department of the Environment, Food and Rural Affairs, 2010. http://randd.defra.gov.uk/Document.aspx?Document=WR0212_8889_TRP.pdf (accessed on 12.12.11). 
[23] Y. Zhang, C.J. Banks, S. Heaven, Anaerobic digestion of two biodegradable municipal waste streams. J. Environ. Manage. 104 (2012) 166-174.

[24] M. Walker, Y. Zhang, S. Heaven, C.J. Banks, Potential errors in the quantitative evaluation of biogas production in anaerobic digestion processes. Bioresour. Technol. 100 (2009) 6339-6346.

[25] APHA, Standard Methods for the Examination of Water and Wastewater, 21st ed., American Public Health Association, American Water Works Association, Water Environment Federation, 2005.

[26] L.E. Ripley, W.C. Boyle, J.C. Converse, Improved alkalimetric monitoring for anaerobic digestion of high strength wastes, J. Water Pollut. Contr. Fed. 58 (1986) 406-411.

[27] ISO 6878, Water quality - Determination of phosphorus - Ammonium Molybdate Spectrometric Method, International Organization for Standardization, 2004.

[28] BioAbfV, Ordinance on the Utilisation of Biowastes on Land used for Agricultural, Silvicultural and Horticultural Purposes (Ordinance on Biowastes - BioAbfV), Federal Law Gazette BGBl, I p. 2955, 1998.

[29] BSI, PAS 110:2010 Specification for Whole Digestate, Separated Liquor and Separated Fibre Derived from the Anaerobic Digestion of Source-segregated Biodegradable Materials. British Standards Institution, London, 2010.

[30] A. Fernandez, A. Sanchez, X. Font, Anaerobic co-digestion of a simulated organic fraction of municipal solid wastes and fats of animal and vegetable origin, Biochem. Eng. J., 26 (2005) 22-28.

[31] K.C. Timberlake, Chemistry: an introduction to general, organic, and biological chemistry, Benjamin Cummings, San Francisco, CA, 2003.

[32] D.G. Cirne, X. Paloumet, L. Bjornsson, M.M. Alves, B. Mattiasson, Anaerobic digestion of lipid-rich waste - effects of lipid concentration, Renew. Energy 32 (2007) 965-975. 
[33] L. Neves, R. Ribeiro, R. Oliveira, M.M. Alves, Enhancement of methane production from barley waste, Biomass Bioenerg. 30 (2006) 599-603.

[34] W.T.M. Sanders, Anaerobic hydrolysis during digestion of complex substrates, $\mathrm{PhD}$ thesis, Wageningen Agricultural University, 2001.

[35] P. Fox, F.G. Pohland, Anaerobic treatment applications and fundamentals: substrate specificity during phase separation, Water Environ. Res. 66 (1994) 716-724.

[36] K. Hanaki, T. Matsuo, M. Nagase, Mechanism of inhibition caused by long-chain fatty acids in anaerobic digestion process, Biotechnol. Bioeng. 23 (1981) 1591-1610.

[37] I.W. Koster, A. Cramer, Inhibition of methanogenesis from acetate in granular sludge by long-chain fatty acids, Appl. Environ. Microbiol. 53 (1987) 403-409. 


\section{Table 1}

Substrate characteristics

mr-OFMSW $\quad$ Sleep blood $\quad$ PI/FF mix

\begin{tabular}{|c|c|c|c|}
\hline \multicolumn{4}{|l|}{ General } \\
\hline $\mathrm{pH}(1: 5$ dilution for OFMSW and PI/FF) & $6.39 \pm 0.01$ & $7.23 \pm 0.06$ & $5.96 \pm 0.04$ \\
\hline TS (\% wet weight (WW)) & $52.83 \pm 0.63$ & $19.7 \pm 0.3$ & $20.8 \pm 0.3$ \\
\hline $\mathrm{VS}(\% \mathrm{WW})$ & $33.55 \pm 0.63$ & $18.9 \pm 0.3$ & $19.4 \pm 0.3$ \\
\hline VS (\% TS) & $63.52 \pm 1.89$ & $95.6 \pm 0.1$ & $93.2 \pm 0.1$ \\
\hline Total organic carbon (TOC) (\% TS) & $34.8 \pm 1.1$ & $42.0 \pm 0.7$ & $45.3 \pm 1.7$ \\
\hline TOC / TKN & $25.0 \pm 1.6$ & $2.85 \pm 0.05$ & $5.85 \pm 0.24$ \\
\hline Biodegradable $\mathrm{C}^{\text {a }} / \mathrm{TKN}$ & $19.2 \pm 1.6$ & $2.85 \pm 0.05$ & $5.58 \pm 0.23$ \\
\hline Calorific value (CV) ( $\left.\mathrm{kJ} \mathrm{g}^{-1} \mathrm{TS}\right)$ & $13.9 \pm 0.2$ & $22.91 \pm 0.25$ & $26.21 \pm 0.01$ \\
\hline \multicolumn{4}{|l|}{ Biochemical composition (VS basis) } \\
\hline Carbohydrates $^{\mathrm{b}}\left(\mathrm{g} \mathrm{kg}^{-1}\right)$ & $340 \pm 7$ & $7.2 \pm 0.6$ & $15.8 \pm 1.1$ \\
\hline $\operatorname{Lipids}^{\mathrm{c}}\left(\mathrm{g} \mathrm{kg}^{-1}\right)$ & $68.6 \pm 5.4$ & BDL & $349 \pm 8$ \\
\hline Crude proteins $\left(\mathrm{g} \mathrm{kg}^{-1}\right)$ & $130 \pm 7$ & $965 \pm 2$ & $538 \pm 8$ \\
\hline Hemi-cellulose $\left(\mathrm{g} \mathrm{kg}^{-1}\right)$ & $52.2 \pm 12.4$ & - & $46.7 \pm 2.4$ \\
\hline Cellulose $\left(\mathrm{g} \mathrm{kg}^{-1}\right)$ & $252 \pm 36$ & - & $46.4 \pm 2.9$ \\
\hline $\operatorname{Lignin}\left(\mathrm{g} \mathrm{kg}^{-1}\right)$ & $184 \pm 26$ & - & $18.6 \pm 2.2$ \\
\hline \multicolumn{4}{|l|}{ NPK and PTE content (TS basis) } \\
\hline Total Kjeldahl nitrogen $(\mathrm{TKN})\left(\mathrm{g} \mathrm{kg}^{-1}\right)$ & $13.9 \pm 0.8$ & $153 \pm 4$ & $77.4 \pm 1.4$ \\
\hline $\mathrm{TP}\left(\mathrm{g} \mathrm{kg}^{-1}\right)$ & $2.17 \pm 0.25$ & $0.835 \pm 0.036$ & $8.10 \pm 0.13$ \\
\hline $\mathrm{TK}\left(\mathrm{g} \mathrm{kg}^{-1}\right)$ & $4.26 \pm 0.37$ & $3.71 \pm 0.11$ & $10.9 \pm 0.1$ \\
\hline $\mathrm{Cd}\left(\mathrm{mg} \mathrm{kg}^{-1}\right)$ & $1.50 \pm 0.37$ & BDL & BDL \\
\hline $\mathrm{Cr}\left(\mathrm{mg} \mathrm{kg}^{-1}\right)$ & $263 \pm 11$ & BDL & $14.6 \pm 0.3$ \\
\hline $\mathrm{Cu}\left(\mathrm{mg} \mathrm{kg}^{-1}\right)$ & $107 \pm 10$ & $6.7 \pm 0.3$ & $37.9 \pm 0.5$ \\
\hline $\mathrm{Hg}\left(\mathrm{mg} \mathrm{kg}^{-1}\right)$ & $0.179 \pm 0.018$ & BDL & BDL \\
\hline $\mathrm{Ni}\left(\mathrm{mg} \mathrm{kg}^{-1}\right)$ & $97.0 \pm 2.9$ & $\mathrm{BDL}$ & $6.9 \pm 0.3$ \\
\hline $\mathrm{Pb}\left(\mathrm{mg} \mathrm{kg}^{-1}\right)$ & $162 \pm 10$ & BDL & BDL \\
\hline $\mathrm{Zn}\left(\mathrm{mg} \mathrm{kg}^{-1}\right)$ & $259 \pm 4$ & $16.3 \pm 0.2$ & $250 \pm 0$ \\
\hline
\end{tabular}




mr-OFMSW $\quad$ Sleep blood $\quad$ PI/FF mix

Elemental composition (TS basis)

\begin{tabular}{lccc}
\hline $\mathrm{N}(\%)$ & $1.32 \pm 0.08$ & $15.3 \pm 0.4$ & $7.74 \pm 0.14$ \\
$\mathrm{C}(\%)$ & $33.0 \pm 1.0$ & $42.1 \pm 0.7$ & $45.6 \pm 1.7$ \\
$\mathrm{H}(\%)$ & $4.80 \pm 0.30$ & $7.33 \pm 0.37$ & $8.04 \pm 0.38$ \\
$\mathrm{~S}(\%)$ & $0.25 \pm 0.04$ & $1.00 \pm 0.02$ & $0.62 \pm 0.03$ \\
$\mathrm{O}(\%)$ & $22.2 \pm 1.2$ & $27.1 \pm 0.9$ & $23.3 \pm 1.7$
\end{tabular}



\footnotetext{
${ }^{a}$ Biodegradable carbon was calculated by deducting lignin carbon from TOC. The formula of lignin was chosen as $\mathrm{C}_{9} \mathrm{H}_{7.95} \mathrm{O}_{2.41}(\mathrm{OMe})_{0.93}$.

${ }^{\mathrm{b}}$ In equivalent glucose.

${ }^{\mathrm{c}}$ n-hexane extractable material (HEM).

${ }^{\mathrm{d}}$ BDL: below the detection limit. Generally the detection limits for the above mentioned analysis are as follows: Lipids-10 $\mathrm{g} \mathrm{kg}^{-1} \mathrm{VS}, \mathrm{Cd}-1 \mathrm{mg} \mathrm{kg}^{-1} \mathrm{TS}, \mathrm{Cr}-2 \mathrm{mg} \mathrm{kg}^{-1} \mathrm{TS}, \mathrm{Hg}-10 \mu \mathrm{g} \mathrm{kg}^{-1} \mathrm{TS}, \mathrm{Ni}-5 \mathrm{mg} \mathrm{kg}^{-1} \mathrm{TS}, \mathrm{Pb}-10 \mathrm{mg} \mathrm{kg}$ ${ }^{1}$ TS.

e Theoretical BMP value was calculated using biochemical composition [17].
} 
Table 2

Characteristics of digestate liquor on a dry weight basis

\begin{tabular}{|c|c|c|c|c|c|}
\hline & \multicolumn{2}{|c|}{ PI/FF co-digestion } & \multicolumn{2}{|c|}{ Sheep blood co-digestion } & \multirow{2}{*}{$\begin{array}{l}\text { mr-OFMSW } \\
\text { control }\end{array}$} \\
\hline & Digester no. 1 & Digester no. 2 & Digester no. 1 & Digester no. 2 & \\
\hline \multicolumn{6}{|l|}{ Nutrients } \\
\hline $\mathrm{TKN}\left(\mathrm{g} \mathrm{kg}^{-1} \mathrm{TS}\right)$ & 65.6 & 75.4 & 72.3 & 108 & 39.9 \\
\hline $\mathrm{TP}\left(\mathrm{g} \mathrm{kg}^{-1} \mathrm{TS}\right)$ & 6.7 & 6.9 & 4.6 & 4.0 & 4.7 \\
\hline $\mathrm{TK}\left(\mathrm{g} \mathrm{kg}^{-1} \mathrm{TS}\right)$ & 15 & 13 & 13 & 14 & 12 \\
\hline \multicolumn{6}{|c|}{ Potentially toxic elements } \\
\hline $\mathrm{Cd}\left(\mathrm{mg} \mathrm{kg}^{-1} \mathrm{TS}\right)$ & 1.2 & 1.3 & 1.3 & 1.2 & 1.5 \\
\hline $\mathrm{Cr}\left(\mathrm{mg} \mathrm{kg}^{-1} \mathrm{TS}\right)$ & 52 & 94 & 48 & 82 & 65 \\
\hline $\mathrm{Cu}\left(\mathrm{mg} \mathrm{kg}^{-1} \mathrm{TS}\right)$ & 350 & 350 & 350 & 340 & 400 \\
\hline $\mathrm{Pb}\left(\mathrm{mg} \mathrm{kg}^{-1} \mathrm{TS}\right)$ & 470 & 480 & 420 & 450 & 530 \\
\hline $\mathrm{Hg}\left(\mathrm{mg} \mathrm{kg}^{-1} \mathrm{TS}\right)$ & 0.59 & 0.61 & 0.59 & 0.61 & 0.77 \\
\hline $\mathrm{Ni}\left(\mathrm{mg} \mathrm{kg}^{-1} \mathrm{TS}\right)$ & 41 & 65 & 42 & 60 & 57 \\
\hline $\mathrm{Zn}\left(\mathrm{mg} \mathrm{kg}^{-1} \mathrm{TS}\right)$ & 800 & 790 & 750 & 780 & 900 \\
\hline \multicolumn{6}{|l|}{ Solids content } \\
\hline TS (\% WW) & 12.3 & 13.9 & 9.71 & 10.2 & 12.2 \\
\hline VS (\% WW) & 6.36 & 6.42 & 5.42 & 6.09 & 5.50 \\
\hline
\end{tabular}


Table 3

Characteristics of digestate fibre on a dry weight basis

\begin{tabular}{|c|c|c|c|c|c|}
\hline & \multicolumn{2}{|c|}{ PI/FF co-digestion } & \multicolumn{2}{|c|}{ Sheep blood co-digestion } & \multirow{2}{*}{$\begin{array}{l}\text { mr-OFMSW } \\
\text { control }\end{array}$} \\
\hline & Digester no. 1 & Digester no. 2 & Digester no. 1 & Digester no. 2 & \\
\hline \multicolumn{6}{|l|}{ Nutrients } \\
\hline $\mathrm{TKN}\left(\mathrm{g} \mathrm{kg}^{-1} \mathrm{TS}\right)$ & 24.2 & 21.8 & 32.4 & 40.2 & 16.5 \\
\hline $\mathrm{TP}\left(\mathrm{g} \mathrm{kg}^{-1} \mathrm{TS}\right)$ & 4.8 & 4.8 & 2.9 & 2.8 & 4.3 \\
\hline $\mathrm{TK}\left(\mathrm{g} \mathrm{kg}^{-1} \mathrm{TS}\right)$ & 6.6 & 6.9 & 4.4 & 4.7 & 5.5 \\
\hline \multicolumn{6}{|c|}{ Potentially toxic elements } \\
\hline $\mathrm{Cd}\left(\mathrm{mg} \mathrm{kg}^{-1} \mathrm{TS}\right)$ & 1.0 & 1.0 & 0.95 & 0.98 & 1.0 \\
\hline $\mathrm{Cr}\left(\mathrm{mg} \mathrm{kg}^{-1} \mathrm{TS}\right)$ & 460 & 510 & 500 & 510 & 665 \\
\hline $\mathrm{Cu}\left(\mathrm{mg} \mathrm{kg}^{-1} \mathrm{TS}\right)$ & 660 & 300 & 560 & 410 & 330 \\
\hline $\mathrm{Pb}\left(\mathrm{mg} \mathrm{kg}^{-1} \mathrm{TS}\right)$ & 300 & 370 & 250 & 314 & 300 \\
\hline $\mathrm{Hg}\left(\mathrm{mg} \mathrm{kg}^{-1} \mathrm{TS}\right)$ & 0.82 & 0.43 & 0.58 & 0.48 & 0.29 \\
\hline $\mathrm{Ni}\left(\mathrm{mg} \mathrm{kg}^{-1} \mathrm{TS}\right)$ & 210 & 230 & 230 & 250 & 300 \\
\hline $\mathrm{Zn}\left(\mathrm{mg} \mathrm{kg}^{-1} \mathrm{TS}\right)$ & 510 & 500 & 390 & 1400 & 530 \\
\hline \multicolumn{6}{|l|}{ Solids content } \\
\hline TS (\% WW) & 28.2 & 29.6 & 27.0 & 28.2 & 30.2 \\
\hline VS (\% WW) & 14.4 & 15.1 & 15.6 & 17.0 & 12.7 \\
\hline
\end{tabular}


Table 4

Characteristics of whole digestate on a dry weight basis

\begin{tabular}{|c|c|c|c|c|c|}
\hline & \multicolumn{2}{|c|}{ PI/FF co-digestion } & \multicolumn{2}{|c|}{ Sheep blood co-digestion } & \multirow{2}{*}{$\begin{array}{l}\text { mr-OFMSW } \\
\text { control }\end{array}$} \\
\hline & Digester no. 1 & Digester no. 2 & Digester no. 1 & Digester no. 2 & \\
\hline \multicolumn{6}{|l|}{ Nutrients } \\
\hline $\mathrm{TKN}\left(\mathrm{g} \mathrm{kg}^{-1} \mathrm{TS}\right)$ & 53.1 & 55.6 & 70.2 & 82.7 & 34.7 \\
\hline $\mathrm{TP}\left(\mathrm{g} \mathrm{kg}^{-1} \mathrm{TS}\right)$ & 6.2 & 6.1 & 4.2 & 3.7 & 4.6 \\
\hline $\mathrm{TK}\left(\mathrm{g} \mathrm{kg}^{-1} \mathrm{TS}\right)$ & 13 & 11 & 11 & 12 & 11 \\
\hline \multicolumn{6}{|c|}{ Potentially toxic elements } \\
\hline $\mathrm{Cd}\left(\mathrm{mg} \mathrm{kg}^{-1} \mathrm{TS}\right)$ & 1.2 & 1.2 & 1.2 & 1.1 & 1.4 \\
\hline $\mathrm{Cr}\left(\mathrm{mg} \mathrm{kg}^{-1} \mathrm{TS}\right)$ & 160 & 250 & 150 & 190 & 220 \\
\hline $\mathrm{Cu}\left(\mathrm{mg} \mathrm{kg}^{-1} \mathrm{TS}\right)$ & 430 & 330 & 400 & 360 & 380 \\
\hline $\mathrm{Pb}\left(\mathrm{mg} \mathrm{kg}^{-1} \mathrm{TS}\right)$ & 430 & 440 & 380 & 420 & 470 \\
\hline $\mathrm{Hg}\left(\mathrm{mg} \mathrm{kg}^{-1} \mathrm{TS}\right)$ & 0.65 & 0.55 & 0.59 & 0.58 & 0.65 \\
\hline $\mathrm{Ni}\left(\mathrm{mg} \mathrm{kg}^{-1} \mathrm{TS}\right)$ & 85 & 120 & 85 & 110 & 120 \\
\hline $\mathrm{Zn}\left(\mathrm{mg} \mathrm{kg}^{-1} \mathrm{TS}\right)$ & 730 & 690 & 670 & 930 & 810 \\
\hline \multicolumn{6}{|l|}{ Solids content } \\
\hline TS (\% WW) & 16.4 & 20.0 & 13.8 & 14.6 & 16.3 \\
\hline VS (\% WW) & 8.48 & 9.33 & 7.68 & 8.72 & 7.47 \\
\hline
\end{tabular}


Fig. 1. Weekly average specific biogas production (SBP), specific methane production (SMP), volumetric biogas production (VBP), volumetric methane production (VMP), and methane content of biogas in co-digestion trials using mr-OFMSW and PI/FF mix, mr-OFMSW and sheep blood mix, and mr-OFMSW only.

Fig. 2. Weekly average $\mathrm{pH}$, total ammoniacal nitrogen (TAN), free ammonia, volatile fatty acids (VFA) in co-digestion trials using mr-OFMSW and PI/FF mix, mr-OFMSW and sheep blood mix, and mr-OFMSW only.

Fig. 3. VFA concentration profiles in co-digestion trials using mr-OFMSW and PI/FF mix, mr-OFMSW and sheep blood mix, and mr-OFMSW only. 
Figure 1
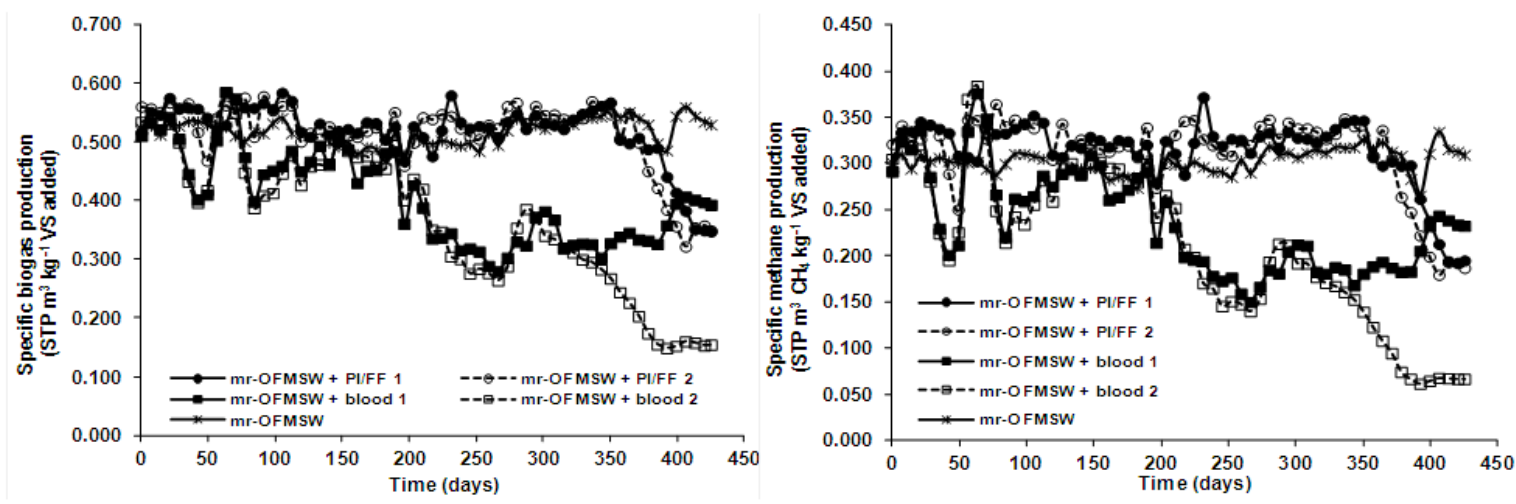

a. Weekly average specific biogas production

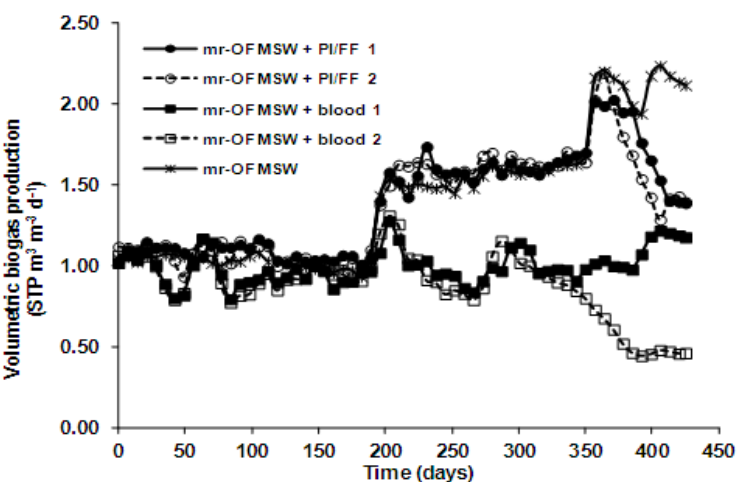

b. Weekly average specific methane production

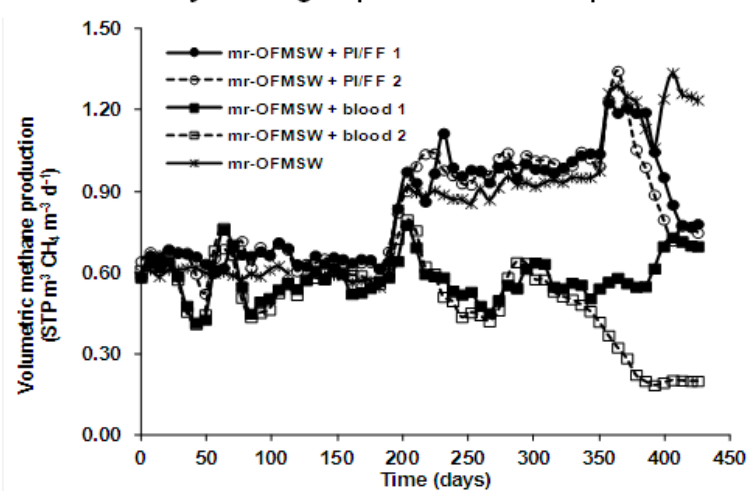

c. Weekly average volumetric biogas production

d. Weekly average volumetric methane production



e. Weekly average methane content of biogas 
Figure 2

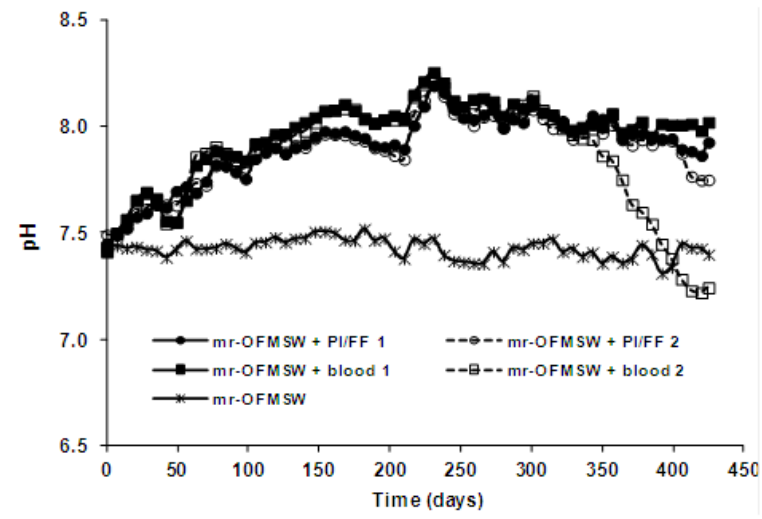

a. Weekly average $\mathrm{pH}$

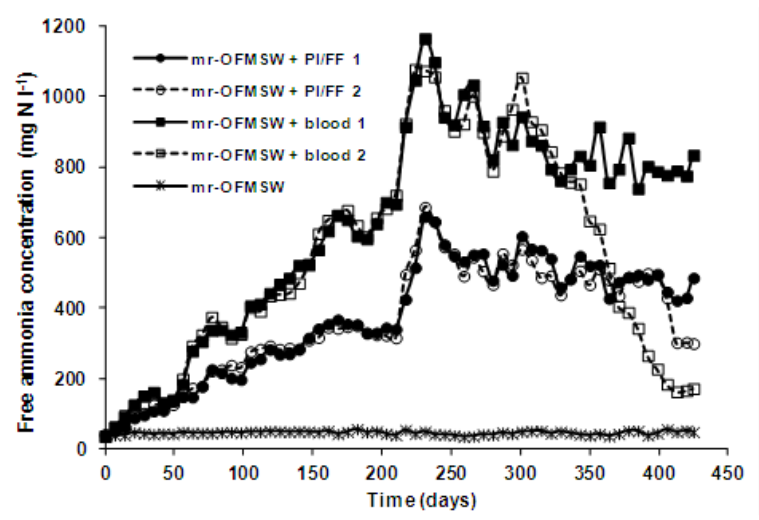

c. Free ammonia concentration

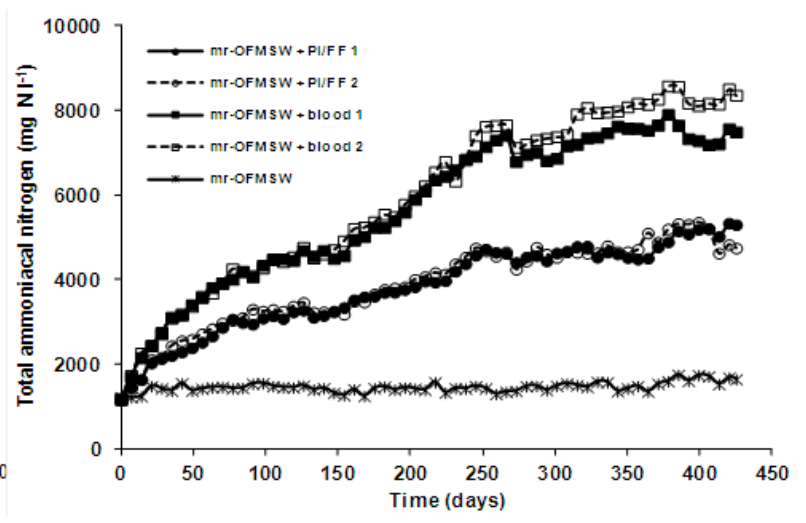

b. Total ammoniacal nitrogen (TAN)



d. Total VFA concentration 
Figure 3

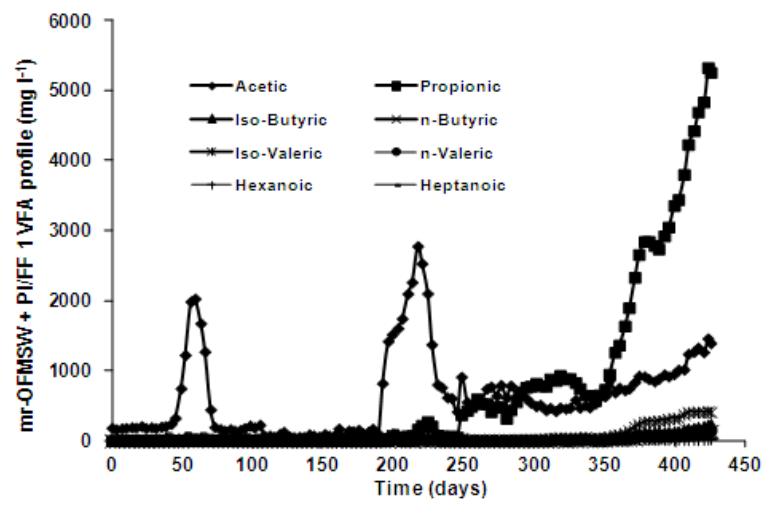

a. VFA concentration profile with PI/FF cosubstrate (digester No.1)



c. VFA concentration profile with sheep blood co-substrate (digester No.1)

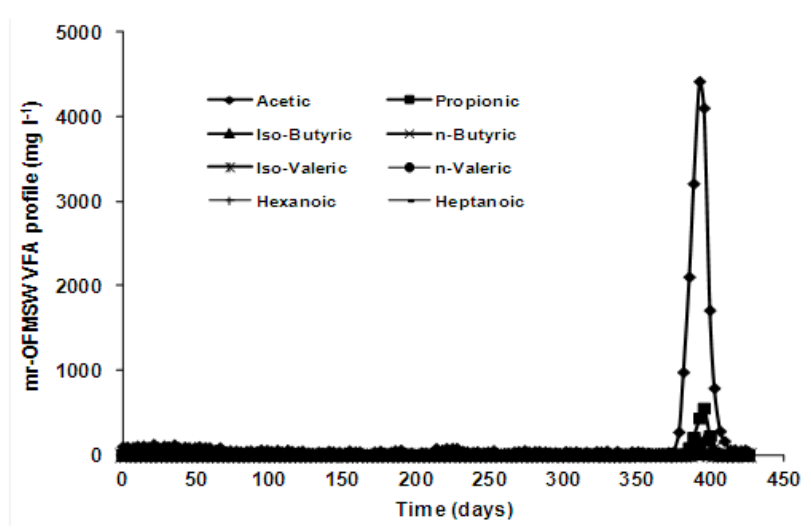

e. VFA concentration profile in mr-OFMSW digester

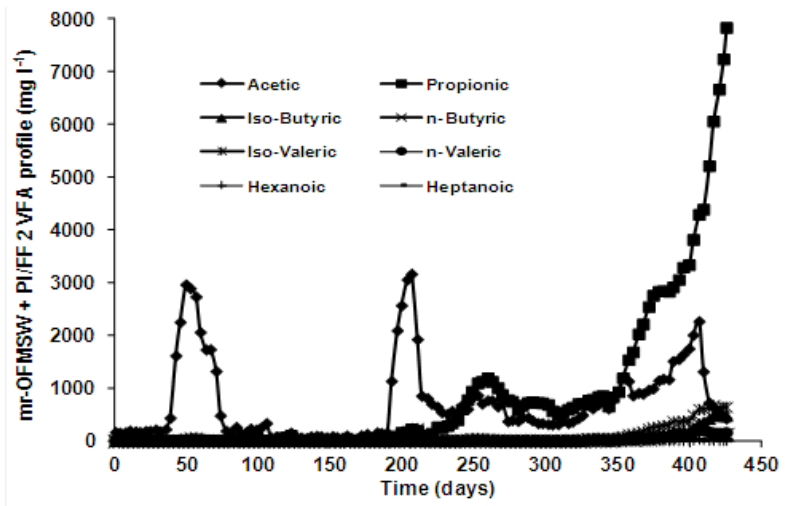

b. VFA concentration profile with $\mathrm{PI} / \mathrm{FF}$ cosubstrate (digester No. 2)

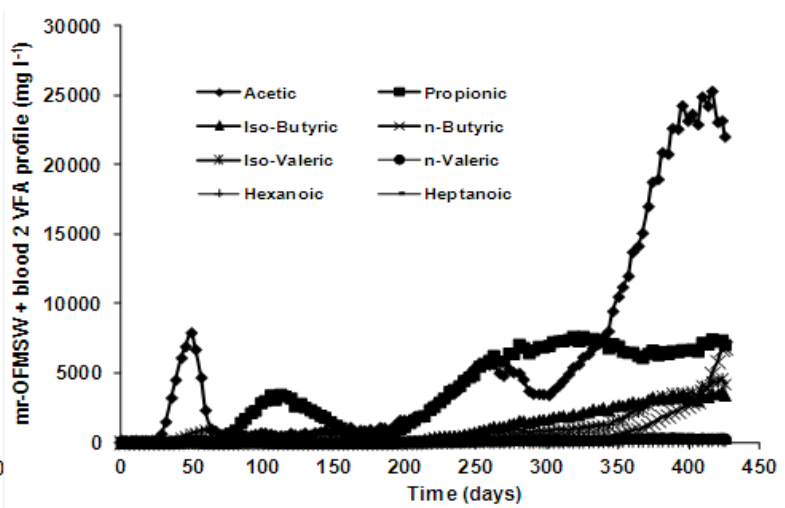

d. VFA concentration profile with sheep blood co-substrate (digester No.2) 